Sebastian Cortés

\title{
CHOREOGRAFIA JAKO STRATEGIA PEDAGOGICZNA: UCIELEŚNIONE PODEJŚCIE DO SZKOLENIA AKTORSKIEGO
}

\section{Wprowadzenie}

Na początku XX w. rosyjski aktor i reżyser teatralny Konstantin Stanisławski rozpoczął długotrwałe badania sztuki i technik aktorskich. Mając na celu stworzenie kompleksowego systemu szkolenia aktorów, zwrócił się ku wiodącym, współczesnym mu psychologom, szczególnie Théodule’owi Ribotowi, którego praca La Psychologie des Sentiments została przetłumaczona na język rosyjski w 1900 r., niecałe cztery lata po jej publikacji w języku francuskim (Blair 2008, s. 30). Jego koncepcja pamięci afektywnej głosi, że emocje, które przeżywa każdy człowiek, tworzą ślady neurologiczne podlegające wolnej woli i mogą być w sposób świadomy uzewnętrzniane. Innymi słowy: uwolnione - jeśli się je właściwie wywoła. Pamięć afektywna stała się podstawą treningu aktorskiego nie tylko w Rosji, lecz także w wielu krajach Zachodu. Metoda dydaktyczna Stanisławskiego, którą można nazwać „psychotechniką, miała szybki i wyrazisty wpływ na świat teatru realistycznego. Nikt przed nim nie próbował stworzyć w pełni rozwiniętego systemu szkolenia aktorów, którzy wraz ze studentami szkół aktorskich, zarówno w Europie, jak i Ameryce, łaknęli takich wskazówek w swoim rozwoju artystycznym.

Wyraźnie widzimy, że tej fazie badań Stanisławski niemal nie brał pod uwagę podstawowego narzędzia, którym aktorzy dzielą się z widzami: ciała jako takiego. Na dalszym etapie swojej kariery Stanisławski uznał braki w swoim systemie. Ponieważ jego zainteresowanie wszystkim, co mogłoby pomóc w lepszym zrozumieniu procesów psychologicznych aktora, nie zmalało przez lata, odwrócił się on od psychotechniki w celu stworzenia tego, co nazywamy Metodą Działań Fizycznych - bardziej skoncentrowanego na ciele podejścia, będącego efektem obiektywnej psychologii i behawioryzmu (Blair 2008, s. 32).

Z wielu powodów, kulturowych i historycznych, Metoda Działań Fizycznych nigdy nie uzyskała takiego zainteresowania, co jej poprzedniczka; nawet dzisiaj 
nazwisko Stanisławskiego jest na ogół kojarzone z jego wczesnymi, zasadniczo kartezjańskimi poglądami na aktorstwo. Pod każdą szerokością geograficzną aktorzy są bowiem nauczani „metodą Stanisławskiego", nakazującą im pracę i kreację w sztucznym rozdziale pomiędzy duchem a ciałem.

W ostatnich dwóch dekadach nowe badania i teorie kognitywistyczne wyparły poprzednią koncepcję relacji między ciałem a umysłem. Podobny zwrot odbywa się w świecie akademickiego szkolnictwa aktorskiego: metody pedagogiczne oparte przede wszystkim na ruchu, zarówno wyreżyserowanym, jak i improwizowanym, stają się coraz popularniejsze. Poprzez dwa podstawowe ćwiczenia - jedno wywodzące się z Treningu Aktorskiego Metodą Suzuki, drugie: z mojej własnej, rozwijanej wciąż metody opartej na relacji interpersonalnej, emocjach i improwizacji ruchowej - chciałbym zaprezentować sposób, w jaki możemy nauczyć się sztuki aktorskiej poprzez ciało, oraz pokazać, jak kognitywistyka może służyć nam teoretycznym wsparciem w pracy teatralnej.

\section{Fizyczne ćwiczenia w treningu aktorskim}

\section{Ćwiczenie nr 2, Powolne Ten Tekka Ten}

Nasz pierwszy przykład wywodzi się z Treningu Aktorskiego Metodą Suzuki - jednego z najpopularniejszych i najbardziej rozpowszechnionych. Japoński reżyser Tadashi Suzuki zaczął rozwijać swoją metodę wraz ze swoją trupą w latach 70. (Allain 2009, s. 57). Metoda ta ma swoje głębokie korzenie w średniowiecznych formach japońskiego teatru kabuki oraz noh, jednak ich klasyczne elementy zostały przekształcone tak, aby tworzyły system rozwoju artystycznego użyteczny dla aktorów pracujących we współczesnym teatrze. Większość ćwiczeń zawiera z góry ustaloną sekwencję ruchów. Są one proste, jednak niezwykle trudne do precyzyjnego wykonania. Często ruchy te stają się także kanwą dla dość swobodnej improwizacji.

Jedno z tych ćwiczeń to Ćwiczenie nr 2, znane także jako Powolne Ten Tekka Ten (Allain 2009, s. 110). Aktorzy stoją w dwóch rzędach na przeciwległych krańcach sceny i rozpoczynają spacer, który kończy się, gdy rzędy zamienią się miejscami. Spacer wymaga ogromnej uwagi, skupienia i opanowania, ponieważ powinien być wykonany równomiernie, bez wzajemnych potrąceń, kołysania się na boki, a także przyspieszenia i zatrzymania; wszystkie ruchy powinny być typowe dla codziennego chodzenia i sprawiać, że środek ciężkości aktora przemieszcza się równo i płynnie. Podczas gdy mięśnie dolnej części ciała pracują intensywnie w celu odbycia spaceru, górna część pozostaje swobodna i skupia się na ekspresji ruchowej. Oprócz wyzwania, jakim jest samo spacerowanie, ćwiczenie wymaga od członków grupy, by działali w idealnej harmonii, wzajemnie dostosowując długość kroku tak, aby rzędy pozostały równe podczas całego ćwiczenia. Rytm 
zapewnia muzyka, która jest kolejnym elementem ćwiczenia wymagającym dużego skupienia. Spacer jest powtarzany kilkakrotnie z niewielkimi zmianami w ruchu ramion.

Podstawowym aspektem, możliwym do znalezienia zarówno w tym ćwiczeniu, jak i w całej metodzie, który upodabnia ją do wszystkich metod fizycznych poznanych przeze mnie do tej pory, jest wykorzystanie obrazów. Obrazem może być każde zdjęcie, myśl, uczucie lub skojarzenie, które aktor może uznać za użyteczne źródło inspiracji, sposób łączenia wyobraźni z ruchem. W ten sposób wykonanie Ten Tekka Ten jest nie tylko zadaniem motorycznym, ale raczej holistycznym zaangażowaniem ciała-umysłu jako nierozdzielnego podmiotu. Obraz, jeżeli jest dobrany właściwie, oddziałuje na pracę mięśni i stawów, a jednocześnie ruch wpływa zwrotnie na wyobrażeniową podróż aktora.

Wybrałem Ten Tekka Ten, aby pokazać, jak ćwiczenie choreograficzne może pomóc $\mathrm{w}$ ucieleśnieniu jednej z podstawowych zasad dramaturgicznych realizmu aktorskiego, mianowicie dualności celów i przeszkód. Zgodnie z tą koncepcją, wprowadzoną przez Stanisławskiego w książce Praca aktora nad sobą, wszystkie działania i intencje jakiejkolwiek dramatycznej postaci można opisać jako walkę o osiągnięcie określonych celów - od głównego celu całej sztuki, poprzez pokonanie szeregu przeszkód, do jednego lub kilku drobnych celów w każdej ze scen. Według terminologii Stanisławskiego, która oczywiście odnosi się przede wszystkim do dramatu realistycznego, przeszkody odpowiadają przeciwstawnym celom drugiej postaci (Merlin 2007, s. 73). Jakkolwiek to nazwać, napięcie (energia), które te przeciwstawne siły tworzą, jest odpowiedzialne za działania i zachowanie postaci.

W ćwiczeniu Suzukiego przeciwstawienie antagonistycznych sił objawia się w kilku formach. W swojej książce The Theatre Practice of Tadashi Suzuki Paul Allain stwierdza, że w ćwiczeniu Ten Tekka Ten „powstaje wrażenie, że ciało jest ciągnięte przez linę przymocowaną do twojego centrum, a jednocześnie pchane w tył z jakąś mniejszą siłą" (Allain 2009, s. 110). Zarazem dodanie obrazu do tego szczególnego, powściągliwego, umiejscowionego w przestrzeni ruchu ustanawia także poznawczą opozycję, jako że odpowiedni obraz powinien skłaniać aktora, by albo dotarł do końca pomieszczenia, albo opuścił punkt wyjścia (podobnie jak np. spiesząc, aby uratować ukochaną osobę przed utonięciem, lub uciekając przed uzbrojonym wrogiem). W konsekwencji przeciwstawienie, pierwotnie będące abstrakcyjną koncepcją dramaturgiczną związaną $\mathrm{z}$ analizą wewnętrznej struktury sztuki, staje się wrażeniem cielesnym, a nie intelektualną wiedzą o roli. Jako takie staje się fizycznym bodźcem, potrafiącym wywoływać uczucia i asocjacje prowadzące do naturalnego, emocjonalnie uzasadnionego, a zatem wiarygodnego zachowania scenicznego, zamiast pozostawić aktora, by wykonywał świadomie wymyślone ruchy, którym według słów Stanisławskiego może brakować tzw. „prawdy wewnętrznej” (Merlin 2007, s. 118). 


\section{Ćwiczenia Relacji}

Po kilku latach pracy ze studentami aktorstwa jako nauczyciel tańca w różnych węgierskich szkołach doszedłem do wniosku, że program nauczania sprawiał wrażenie, iż lekcje tańca i ruchu były całkowicie podległe lekcjom gry aktorskiej. Wynikiem tego hierarchicznego rozróżnienia było zaostrzenie dychotomicznego sposobu myślenia, które już zostało uwydatnione w szkoleniu aktorów metodą Stanisławskiego. Ruch był wyłącznie umiejętnością nabywaną w celu przygotowania aktorów do wykonywania potencjalnych zadań polegających na tańcu, akrobatyce itp. Moi studenci nie byli zdolni do wykorzystania tego, czego nauczyli się na lekcjach aktorstwa, podczas zajęć tanecznych - i na odwrót. Chciałem w jakiś sposób wypełnić tę lukę, która moim zdaniem była bezproduktywna, sztuczna i sprzeczna z ludzką naturą. Podczas zajęć zacząłem eksperymentować z improwizacją ruchową, wprowadzając jako źródło inspiracji i motywacji kontekst dramatyczny.

Efekty były oszałamiające. Nie tylko radykalnie poprawiła się jakość ruchu moich podopiecznych, lecz także ich moce wykonawcze. Nawet ci najmniej zdolni z grupy stali się sugestywni i interesujący na tyle, że musiałem włożyć wiele wysiłku, by przestać skupiać się na nich zbyt długo i aby cała grupa otrzymała tyle samo mojej uwagi. Właśnie to doświadczenie skłoniło mnie do rozległych badań i do pisania pracy doktorskiej na temat fizycznych metod szkolenia aktorskiego, prawie nieznanych do tej pory w akademickim kształceniu aktorów na Węgrzech.

Te pierwsze eksperymenty stopniowo przekształciły się w zestaw ćwiczeń, spośród których Ćwiczenia Relacji, gdy piszę te słowa, są najbardziej wyraziste i owocne. $W$ ćwiczeniu podstawowym dzielę grupę studentów na pary. Jedna studentka (nazwijmy ją A) wyobraża sobie obraz rzeczywistej lub fikcyjnej relacji, która ma za cel palącą potrzebę zakomunikowania czegoś partnerce (B), niezależnie od tego, czy jest to rzeczywista osoba stojąca naprzeciw, czy partnerka zastępuje postać z tej relacji. Stoją w odległości dwóch metrów od siebie. A pozwala swojemu stanowi emocjonalnemu, skojarzeniom $\mathrm{z}$ daną relacją ustalonym przez wybrany obraz i jego zawartość komunikatywną, prowadzić swoje ciało w swobodnej improwizacji ruchowej. Zadaniem B jest obserwowanie w bezruchu, skupiając pełną uwagę na wysyłającym komunikat ciele partnerki. Tak jak B zdaje się pełnić rolę pasywną w tym ćwiczeniu, jej obecność jest w rzeczywistości bardzo aktywna. Jej głębokie, ciągłe skupienie, spontaniczne reakcje emocjonalne, choć niewyrażone w żaden sposób bezpośrednio, mają niewątpliwy wpływ na A i stają się czynnikiem, który może radykalnie zmienić także sposób improwizacji. W kolejnej odmianie ćwiczenia pozwalam B zareagować poprzez jej własną improwizację ruchową, równoległą, choć nie niezależną od pierwotnego źródła impulsów pochodzących od A. W kolejnej fazie improwizujące partnerki mają także swobodę kontaktu fizycznego, który może wahać się od delikatnego dotknięcia dłoni do bardziej akrobatycznych figur i wspólnego 
tańca. Nie ma jakichkolwiek ograniczeń, o ile żaden wykonywany ruch nie wykracza poza kontekst wynikający z obrazu, a ciało nie jest używane do ekspresji wewnętrznego procesu poprzez gesty.

Stopień powiązania, jaki te ćwiczenia tworzą, znacznie wykracza poza codzienność. Studentki regularnie donoszą o pozyskaniu wzajemnej „głębokiej wiedzy" o sobie, której nie można ująć słowami; osiągają rzadko spotykaną otwartość w stosunku zarówno do pracy, jak i partnera, a także silne poczucie obecności $\mathrm{w}$ danych okolicznościach. Ten stopień niewerbalnej komunikacji i wymiana energii jest moim zdaniem esencją aktorstwa - jakością, którą czasem nazywamy obecnością aktora.

\section{Podejście kognitywistyczne}

Aby wiarygodnie wyjaśnić to zjawisko, proponuję spojrzenie na koncepcję recesywnego ciata, jak to określa filozof Mark Johnson, oraz definicję świadomości poznawczej Evana Thompsona. Według Marka Johnsona „skuteczne funkcjonowanie naszych ciał wymaga, aby nasze organy i funkcje ciała wycofywały się, a nawet ukrywały w trakcie naszych aktów doświadczania rzeczy w świecie" (zob.: Kemp 2012, s. 16). Evan Thompson stawia krok dalej, rozszerzając rolę nieświadomości także do podstawowych funkcji poznawczych. Według jego własnych słów „świadomość poznawcza obejmuje takie procesy ucieleśnionej i osadzonej świadomości oraz emocji, które są niedostępne danej osobie na drodze eksperymentu (zob. Lutterbie 2011, s. 97). Nieco zmieniłbym to stwierdzenie z „niedostępne” na „nie bezpośrednio dostępne”, co oznacza, że ucieleśnione emocje mogą być niedostępne dla świadomego umysłu, ale na pewno mają na niego wpływ. Moje przypuszczenie co do świadomego postrzegania nieświadomej treści poznawczej popiera teoria emocji przedstawiona przez Antonio Damasio. Uważa on, że emocje są nieświadomymi fizycznymi reakcjami ciała na pewne stymulacje (Kemp 2012, s. 164). Stajemy się świadomi ogólnego stanu psychicznego, który identyfikujemy jako uczucia, kiedy rejestrujemy trzewną reakcję naszego ciała na konkretny bodziec. Zmiany w naszym tętnie, tempie oddychania, ciśnieniu krwi i inne bodźce informuja nas, że doświadczamy uczucia (Damasio 1994). W ten sposób nieświadome zdarzenia poznawcze wyłaniają się ponad naszym progiem świadomości, aby można je było traktować w sposób behawioralny.

Raczej dyskusyjnym, lecz użytecznym dodatkiem do powyższego są modne wyniki badań systemu neuronów lustrzanych. Po tym, jak Giacomo Rizzolatti odkrył istnienie w mózgu ludzkim oraz naczelnych systemu neuronów, które wysyłają impulsy zarówno gdy dany osobnik wykonuje czynność, jak i wtedy, gdy obserwuje tę samą czynność u innego osobnika (Blair 2008, s. 13), powstało wiele teorii dotyczących celu istnienia i funkcjonowania tych neuronów. Lustrzane neurony mogą być odpowiedzialne za nauczanie we wczesnym dzieciństwie, 
a także być neuronową podstawą empatii. Sandra Blakeslee twierdzi, że ludzki mózg może mieć „wiele systemów neuronów lustrzanych, które specjalizują się w wykonywaniu i rozumieniu nie tylko działań innych, lecz również ich intencji, społecznego znaczenia ich zachowań oraz ich emocji” (cyt. za: Blair 2008, s. 13). Zestawienie tych przypuszczeń z koncepcją recesywnego ciała i teorii ucieleśnionych emocji Damasio daje nam potencjalną interpretację efektu Ćwiczeń Relacji. Komunikacja poprzez niegestykulacyjną improwizację ruchową uwalnia umysł od myślenia powyżej progu świadomości, umożliwiając aktorom dotarcie do nieświadomości poznawczej, koncentrowanie się na swoich ciałach oraz doświadczanie i pracę z emocjami na głębszym, jak najbardziej ucieleśnionym poziomie.

\section{Wnioski}

Stanisławski zwrócił się ku psychologii, tworząc system, który stał się biblią aktorstwa. Współcześnie zarówno nauczyciele teatru, jak i pedagodzy obawiają się, że nauka najwyraźniej niesie groźbę rozproszenia magicznej mgiełki, która otacza sztukę. Jestem zwolennikiem przeciwnego stanowiska. Nauka, a przede wszystkim badania kognitywne, może pomóc w zrozumieniu naszej sztuki, wyjaśnić nasze procesy artystyczne i umożliwić nam porzucenie dotychczasowych przestarzałych kartezjańskich oczekiwań odnośnie do tego, na czym powinien polegać proces twórczy w teatrze. I cały czas, ujawniając cudowne sposoby radzenia sobie organizmu ludzkiego z egzystencją, może inspirować naszą sztukę, tak jak potrafi to robić niewiele innych dyscyplin. Mam nadzieję, że przyszłość zbliży sztukę i kognitywistykę jeszcze bardziej, jako że coraz więcej artystów i badaczy angażuje się w projekty interdyscyplinarne. Naszym zadaniem jest teraz popularyzowanie takich wzbogacających i satysfakcjonujących spotkań.

Przekład: Grzegorz Stabeusz

\section{Bibliografia}

Allain P. (2008), The Theatre Practice of Tadashi Suzuki, Methuen Drama, London.

Blair R. (2008), The Actor, Image, and Action - Acting and Cognitive Neuroscience, Routledge, London-New York.

Damasio A. (1994), Descartes' Error-Emotion, Reason and the Human Brain, Avon Books, New York.

Johnson M. (2008), The Meaning of the Body, University of Chicago Press, Chicago.

Kemp R. (2012), Embodied Acting, Routledge, London-New York.

Lenzen M. (2005), Feeling Our Emotions, Interview with Antonio Damasio, „Scientific American Mind", April $1^{\text {st }}$.

Lutterbie J. (2011), Toward a General Theory of Acting - Cognitive Science and Performance, Palgrave Macmillan US, New York. 
Merlin B. (2007), The Complete Stanislavski Toolkit, Nick Hern Books, London.

Stanislavski K. (1989), An Actor Prepares, Routledge, New York.

Suzuki T. (1987), The Way of Acting, Theatre Communications Group, New York.

Suzuki T. (2015), Culture is the Body, Theatre Communications Group, New York.

Thompson E. (2007), Mind in Life: Biology, Phenomenology, and the Sciences of Mind, Harvard University Press, London.

\section{Summary}

Like so many other things in so-called Western culture, actor training today lies predominantly upon the Cartesian concept of mind-body dualism. Even though actors, not unlike dancers, have their bodies as a primary tool to work with, the misinterpreted heresy of Konstantin Stanislavsky, the first theatre practitioner to develop a comprehensive pedagogical method for acting, has created a counterproductive, detached relationship between actors and their own bodies.

During the past two decades, due to current research and new theories in cognitive science, a paradigmatic shift has overwritten our previous notion regarding the connection between body and mind. A very similar process is taking place in the artistic field as physical approaches of actor training are gaining a popularity never seen before. Holistic methods like Viewpoints Technique, the Suzuki Method of Actor Training, and Stephen Wangh's Acrobatics of the Heart address key elements of the craft of acting, such as emotions and imagination, through the systematic use of choreography and movement improvisation.

How can "just dancing" lead to a deeper understanding of the actors' on-stage emotional life? While physical methods of actor training offer a pragmatic answer to the question, the work of leading researchers in the cognitive field may explain the way these methods actually work. 